\title{
Assessment and Development of Communicative Skills in English: A Case Study of 1st Year Undergraduate Students Learning English As Their Major
}

\section{Evaluación y desarrollo de habilidades comunicativas en inglés: un estudio de caso de estudiantes de pregrado de primer año que aprenden inglés como su especialidad}

\author{
A.V. Ivanova* \\ North-Eastern Federal University n.a. M.K. Ammosov, Yakutsk, Russia \\ ORCID: https://orcid.org/0000-0001-6373-9951 \\ L.A. Atlasova \\ North-Eastern Federal University n.a. M.K. Ammosov, Yakutsk, Russia \\ ORCID: https://orcid.org/0000-0003-0258-6618

\section{M.B. Sidorova} \\ North-Eastern Federal University n.a. M.K. Ammosov, Yakutsk, Russia \\ ORCID: https://orcid.org/0000-0001-9945-6224
}

*Correspondence

Email: professor.ivanova@mail.ru
Cite as:

\begin{abstract}
Ivanova, A.V., Atlasova, L.A., \& Sidorova, M.B. (2020). Assessment and Development of Communicative Skills in English: A Case Study of 1st Year Undergraduate Students Learning English As Their Major. Propósitos y Representaciones, 8 (SPE2), e630. Doi: http://dx.doi.org/10.20511/pyr2020.v8nSPE2.630
\end{abstract}




\section{Summary}

This article discusses the unique experiences and methods of independent examination of the level of communicative (specifically receptive and productive) English language skills of the first year undergraduate students studying English as the first foreign language in a Russian university, who previously passed the Unified State Exam (USE) in English. The results analyzed came from the tests the students took at the beginning of their first academic year. This study attempts to lay the foundations for the transition to level-oriented learning or to introduce differentiation in groups where students' levels range widely - from A1 to C1. The assessment of the English language proficiency of students studying Philology, Linguistics, Foreign Regional Studies, and Pedagogy was carried out in the format the B2 First Cambridge exam (FCE). The results of the assessment were used to analyze their level of language knowledge and language skills according to the Common European Framework of Reference for Languages: Learning, Teaching, Assessment (CEFR). A number of typical mistakes made by students were revealed, based on which the students as well as their teachers were offered a number of recommendations to improve each of the skills.

Keywords: Assessment of Foreign Language Proficiency; Communicative Competence; LevelOriented Learning; Differentiated Learning; Cambridge Exams; CEFR.

\section{Resumen}

Este artículo analiza las experiencias únicas y los métodos de examen independiente del nivel de habilidades comunicativas (específicamente receptivas y productivas) del idioma inglés de los estudiantes universitarios de primer año que estudian inglés como primer idioma extranjero en una universidad rusa, que previamente aprobó el Examen estatal unificado (USO) en inglés. Los resultados analizados provienen de las pruebas que los estudiantes tomaron al comienzo de su primer año académico. Este estudio intenta sentar las bases para la transición al aprendizaje orientado a niveles o para introducir la diferenciación en grupos donde los niveles de los estudiantes varían ampliamente: de A1 a C1. La evaluación del dominio del idioma inglés de los estudiantes que estudian Filología, Lingüística, Estudios Regionales Extranjeros y Pedagogía se realizó en el formato del examen B2 First Cambridge (FCE). Los resultados de la evaluación se utilizaron para analizar su nivel de conocimiento de idiomas y habilidades linguísticas de acuerdo con el Marco Común Europeo de Referencia para las Lenguas: Aprendizaje, Enseñanza, Evaluación (MCER). Se revelaron una serie de errores típicos cometidos por los estudiantes, en función de los cuales se les ofreció a los estudiantes, así como a sus maestros, una serie de recomendaciones para mejorar cada una de las habilidades.

Palabra clave: Evaluación de dominio de lenguas extranjeras; Competencia comunicativa; Aprendizaje orientado a niveles; Aprendizaje diferenciado; Exámenes de Cambridge, MCER

\section{Introduction}

Russian higher education is undergoing modernization in the field of teaching of foreign languages - the level-oriented approach is being introduced in accordance with the international requirements of the Common European Framework of Reference (hereinafter CEFR). In particular, such changes are occurring at the North-Eastern Federal University n.a. M.K. Ammosov in Yakutsk (Russia) (hereinafter NEFU). It is possible to confirm the level of English language proficiency based on international standards by passing international exams such as the Cambridge English exams, the certificate of which has no expiry date (Atlasova et al., 2019; Cambridge English Qualifications on the CEFR, 2018). The unique Cambridge exam system, built on the basis and in strict accordance with the levels outlined in CEFR, helps to understand how well the candidate can use English language as a means of communication from the elementary level (A1) to the highest level (C2). The results of the exam are recognized in most countries of the world, as they are a reliable tool to prove the language knowledge level (Atlasova et al., 2019; Cambridge Assessment English, 2018). All exams thoroughly test both receptive 
(listening and reading) and productive (writing and speaking) skills. A separate section of assignments is aimed at testing the knowledge of grammar and vocabulary (Atlasova et al., 2019).

In the process of learning a foreign language in the Russian educational system at the level of secondary education, students must reach the Intermediate level (Threshold in accordance with CEFR) (Atlasova et al., 2019; Gorokhova et al., 2017; Council of Europe, 2001); the students taught in the framework of advanced study programmes are to reach the Vantage level (Table 1) (Atlasova et al., 2019; Gorokhova et al., 2017). Thus, the Russian Unified State Exam taken in grade 11 (hereinafter USE) is oriented to CEFR competencies - successful passing of the exam confirms the level of communicative competence equivalent to B2 (Vantage) according to CEFR, and Level 3 Upper-Intermediate according to the Association of Language Testers in Europe (ALTE) (Atlasova et al., 2019; Mescheryakov, 2018). It should be noted that the difficulty of USE tasks varies and includes the three following levels: 'basic' - A2+, 'increased difficulty' B1, and 'high' - B2 (Atlasova et al., 2019; The Specification of Control Measuring Materials for the Unified State Exam in Foreign Languages in 2018).

According to the above information, it is understood that school graduates who pass the USE possess the communicative competence corresponding to level B2 (Upper-Intermediate). This level corresponds to the First Certificate in English Cambridge exam (hereinafter FCE), the results of which can confirm levels B1 (Intermediate) or B2 (Upper-Intermediate), or C1 (Advanced) (Table 1) (Atlasova et al., 2019).

Table 1.

The system of assessment of the communicative competence level in \% ratio used by the Language Center of NEFU Institute of Modern Languages and International Studies

\begin{tabular}{cc}
\hline $85-100 \%$ & $\mathrm{C} 1$ (Advanced) \\
\hline $60-84 \%$ & $\mathrm{~B} 2$ (Upper-Intermediate) \\
\hline $45-59 \%$ & B1 (Intermediate) \\
\hline $0-44 \%$ & A2 (Elementary) and lower \\
\hline
\end{tabular}

The Cambridge FCE exam allows to identify not only the overall level of English language proficiency but also the level of receptive (Reading, Listening) and productive skills (Speaking, Writing), as well as the level of grammar and vocabulary knowledge (Use of English).

In accordance with this approach, to measure the communicative competence of the first year undergraduate students with specialization in Philology, Linguistics, Pedagogy, and Foreign International Studies at NEFU, who study English as their major (the first foreign language), took a test in the format of FCE. The test was conducted at the beginning of the academic year, since the students had entered the university after passing the USE in English, i.e., with a certain minimum knowledge of the English language. It is necessary that students studying in these courses have a minimum English proficiency level of B1 (Intermediate) to learn and effectively comprehend the course material. In this regard, the aim of the study is to identify the level of development of receptive and productive skills in the language which is their major field of study. This goal could be achieved through the following tasks:

1. Testing in FCE format.

2. Independent analysis of the results.

3. Identification of typical mistakes and development of recommendations for improving the receptive and productive skills. 


\section{Literature Review}

The Common European Framework of Reference for Languages: Learning, Teaching, Assessment (CEFR) was developed by the Council of Europe. Moscow State Linguistic University published a Russian translation of the monograph in 2003. The issues related to level monitoring in the process of studying a foreign language and language proficiency assessment have been a topic of research conducted by a number of Russian scientists (Denisova I.A., Gorokhova A.I., Popova E.M., Sidorova M.B., Mescheryakov D. and others); research into the development of communicative and linguistic competences was done by Khutorskoi A.V., Volovikova M.L., Zvyagintseva E.P., Kaplun O.A., Karuk E.V., Makeeva S.G. and others; language skills (receptive and productive) were monitored by Zimnyaya I.A., Votrushina N.U., Galskova N.D., Gez N.I., Jelukhina N.V., Dadiani T.M., Kornienko E.R., Shevchenko N.I., Beretskaya E.A., Folomkina S.K., Graves M. F., Juel, Graves B. B., McDonald K., Numan D., Nuttall C., Pang E. S., Angaluki Muaka, Bernhardt E. B., and others. Let us consider the definitions of the basic concepts according to the interpretations of the Russian researchers.

Speech activity is an active, pragmatically oriented process of transmitting and receiving messages dependent on the communicative situation, which is expressed through language and involves language skills. As mentioned above, the types of language skills differ in nature productive (speaking and writing) and receptive (listening and reading).

According to the definition by Zimnyaya I.A., there are three forms of speech activity:

- oral (social) speech: expressive (informal) speech and impressive speech (i.e., speech perception and understanding);

- written speech (including writing and reading);

- inner speech, which provides for and mediates the first two types of speech—oral and written.

The main forms of oral expressive speech are monologue, dialogue, and polylogue. All of these types can be defined by the general concept of spontaneous speech. These types constitute live colloquial language (Zimnyaya, 2001).

According to Vtorushina N.U., written speech is considered a creative communicative skill understood as the ability to express thoughts in writing. To do this, one must have spelling and calligraphic skills, the ability to compositionally build and shape a written work of speech composed in the form of internal speech, as well as the ability to choose adequate lexical and grammatical units (Vtorushina, 2010).

Speaking of productive skills, it should me said that writing is a creative task, which, in addition to subject knowledge and skills, tests the analytical skills of students and their ability to reason, express and argue their point of view, and to give counter arguments in a model discussion situation.

As far as listening skills are involved, according to some approaches to methodology, following Galskova N.D., Gez N.I., and Elukhina N.V., on the one hand, listening is considered one of the types of speech activity (particularly receptive) that needs to be taught; on the other hand, it is a way of building foreign language communication (Galskova \& Gez, 2006; Gez, 1981; Jelukhina, 1989).

As for another receptive skill - reading, Russian researchers Dadiani T.M., Kornienko E.R., and Shevchenko N.I. divide reading into the following categories: reading with selective extraction of information, reading with understanding of the main content, and reading with full understanding of a text (Dadiani, 2011; Kornienko, 1996; Shevchenko, 2002). Along with these 
concepts, there is also a classification of reading types developed by Folomkina S.K.: learning, introductory, viewing, and searching (Folomkina, 1980). According to Beretskaya E.A., learning reading is aimed at penetrating the meaning of a text through its analysis; the fullness and accuracy of understanding is assumed (Beretskaya, 2016). Introductory reading is an extraction of the main information; it is common for large texts. The aim of viewing reading is to get general information about the meaning of a text. And finally, searching reading is aimed at the extraction of specific information.

On the other hand, foreign researchers Graves M. F., Juel C., Graves B. B., and Numan D. divide reading into the following types: scanning (reading for specific information), skimming (reading for gist), and reading for detailed comprehension (reading for detail) (Graves et al., 1998; Numan \& Lamb, 1996; Al-Ameedi et al., 2019). Scanning is a process during which a reader looks at a text and focuses on specific information that is useful for them. This type of reading is often used with travel books, notes, advertisements, and similar text types. Skimming a text, a reader looks for necessary information throughout the whole text-for example, in a newspaper or a magazine. Understanding of the text meaning during skimming is quite low and superficial. Reading for detailed comprehension, however, implies deep and contemplative reading. According to Douglas B. H. and Heekyeong L., this type of reading helps learners to study words in their context and save information in the long-term memory (Douglas \& Heekyeong, 2015).

\section{Materials and Methods}

The format used in testing is FCE Cambridge exam, which consists of 4 papers.

Table 2.

Format of the FCE exam (Cambridge Assessment English, 2018)

\begin{tabular}{|c|c|c|}
\hline Paper & Content & Purpose \\
\hline $\begin{array}{l}\text { Reading and } \\
\text { Use of English } \\
(1 \mathrm{~h} 15 \mathrm{~min})\end{array}$ & $\begin{array}{l}7 \text { parts. } \\
52 \text { questions. } \\
\text { Parts } 1-4 \text { are related to Grammar and } \\
\text { Vocabulary and amount to } 36 \text { points (every } \\
\text { right answer in parts } 1-3 \text { gets } 1 \text { point, in part } \\
4-2 \text { points). } \\
\text { Parts } 5-7 \text { are related to Reading: there are } 22 \\
\text { tasks amounting to } 34 \text { points (every right } \\
\text { answer in parts } 5-6 \text { gets } 2 \text { points, in part } 7- \\
1 \text { point). } \\
\text { Tasks } 1-3 \text { include texts with concurrent } \\
\text { grammar and vocabulary. Task } 4 \text {, which } \\
\text { includes pairs of sentences and requires to fill } \\
\text { in a gap in the second sentence, is meant to } \\
\text { check the knowledge of grammar and } \\
\text { vocabulary. Tasks 5-7 include several texts } \\
\text { and are meant to check reading skills and } \\
\text { understanding of the content (Atlasova et al., } \\
2019 \text {; Cambridge Assessment English, } \\
2018 \text { ). }\end{array}$ & $\begin{array}{l}\text { Candidates are expected to } \\
\text { demonstrate their skills in } \\
\text { understanding different types } \\
\text { of texts, such as fiction, } \\
\text { newspapers, and magazines; } \\
\text { skills in grammar and } \\
\text { vocabulary. }\end{array}$ \\
\hline $\begin{array}{c}\text { Writing } \\
\text { (1 h } 20 \text { min })\end{array}$ & $\begin{array}{l}2 \text { parts. Each part amounts to } 20 \text { points, } 40 \\
\text { points in total. } \\
\text { The first task is obligatory, without it the } \\
\text { second task cannot be submitted to review. }\end{array}$ & $\begin{array}{l}\text { Candidates are expected to } \\
\text { show their skills in writing } \\
\text { various text types, such as }\end{array}$ \\
\hline
\end{tabular}


The $1^{\text {st }}$ part specifies the essay assignment and suggests two ideas, on the basis of which an essay should be written. Moreover, candidates are expected to add their own, third idea to the essay, different from the first two, but still compliant with the essay theme. The $2^{\text {nd }}$ part suggests 4 types of writing tasks to choose from: article, email (formal or informal)/letter, report or review.

Candidates are supposed to write 140-190 words for each task in 1 hour 20 minutes (Atlasova et al., 2019; Cambridge Assessment English, 2018).

\begin{tabular}{c}
\hline Listening \\
(approximately \\
40 min)
\end{tabular}
4 parts.

30 questions. This section of the exam amounts to 30 points, each completed task brings 1 point.

Candidates are allowed to listen to each task two times.

In the $1^{\text {st }}$ task, candidates have to carefully listen to a series of monologues and dialogues and answer a multiple-choice question.

In the $2^{\text {nd }}$ task-Sentence Completioncandidates have to listen to a monologue (34 minutes long) and fill the gaps in the text using the information they hear.

In the $3^{\text {rd }}$ task-Multiple Matchingcandidates are supposed to listen to 5 short monologues and match five questions with five corresponding answers.

The $4^{\text {th }}$ part includes an interview or a dialogue (3-4 minutes long), after listening to which candidates need to answer 7 multiplechoice questions (Atlasova et al., 2019; Cambridge Assessment English, 2018). article, email (formal or informal)/letter, report or review.

Candidates are expected to demonstrate their skills in listening and understanding verbal material, such as news show, presentations, everyday conversations. 


\begin{tabular}{|c|c|c|}
\hline $\begin{array}{l}\text { Speaking } \\
\text { (14-20 minutes, } \\
\text { depending on } \\
\text { the number of } \\
\text { participants) }\end{array}$ & $\begin{array}{l}4 \text { parts. This stage of the exam amounts to } 25 \\
\text { points: } 20 \text { points can be given in analytical } \\
\text { assessment which involves } 4 \text { criteria and } 5 \\
\text { points are given in holistic assessment for } \\
\text { Global Achievement. } \\
\text { In the } 1^{\text {st }} \text { part candidates answer the questions } \\
\text { of the examiner ( } 2-3 \text { minutes). The questions } \\
\text { are related to candidates' likes and dislikes, } \\
\text { certain life events, media, etc. } \\
\text { In the } 2^{\text {nd }} \text { part candidates are given two } \\
\text { pictures and asked to describe the situations, } \\
\text { and answer a question related to them ( } 4-6 \\
\text { minutes). } \\
\text { The } 3^{\text {rd }} \text { part is a two-way conversation } \\
\text { between candidates related to a theme, set by } \\
\text { the examiner (4-5 minutes). } \\
\text { In the final part of the Speaking stage, the } \\
\text { examiner asks candidates a number of } \\
\text { questions, the themes of which are compliant } \\
\text { with the estimated level of English language } \\
\text { proficiency (1-6 minutes). }\end{array}$ & $\begin{array}{l}\text { Candidates are expected to } \\
\text { effectively communicate in } \\
\text { face-to-face situations. The } \\
\text { Speaking part is conducted in } \\
\text { groups of two or three } \\
\text { candidates at the same time. }\end{array}$ \\
\hline
\end{tabular}

\section{Results}

Fifty-one participants took part in the survey, and each of them took the test including 5 sections (Reading and Use of English, Listening, Writing, Speaking). The results of the study helped to reveal the following. The group of linguistics students (8 participants) gained the highest scores in the Speaking paper with the average score of 12.6 points, which is $63 \%$ success rate. The lowest score was earned in the Use of English paper, where the average score was $45 \%$. Three of the students in the group confirmed a high level of English language proficiency (level B2); one of the students had level A2, which, according to the established guidelines, is insufficient for studying at a language institute (Atlasova et al., 2019).

The Foreign International Studies students earned the highest scores on the Speaking paper, with a total score of $64 \%$. The least successful result in this group was for the Use of English paper, where the percentage of completed tasks reached only $28.98 \%$. One student in the group confirmed level B2, with four students at level A2. One participant in the group displayed the highest level - C1 (Atlasova et al., 2019).

The results of the Philology students' group are as follows: total score for Speaking was 63.75\%; overall average result for Use of English was 54.14\%. Two of the participants demonstrated the highest level of $\mathrm{C} 1$, and one participant was ranked at level B2 (Atlasova et al., 2019).

The largest group in the study was represented by Pedagogical Education students, with 26 participants. Their results are as follows: the highest score was earned in Writing at $57.16 \%$, and the lowest score was for the Use of English paper. Eight participants had level B2, 10 participants demonstrated A2, and one of the participants displayed C1 level (Atlasova et al., 2019).

According to these results, we can draw the following conclusions: the groups were most successful in the Speaking paper, with a total of 58.4\% of answers being correct. The Use of 
English paper showed the worst results. Thirteen students (25.5\%) confirmed level B2, and four students $(8 \%)$ had level $\mathrm{C} 1$, which is $33.3 \%$ of the total number of first year students tested. Fourteen students (27.5\%) had level B1, and 20 students (39\%) were at level A2 (Atlasova et al., 2019).

\section{Conclusion}

Thus, the total number of people who confirmed level $\mathrm{C} 1$, according to the FCE rating scale, was only $4(8 \%), 13$ people $(25.5 \%)$ showed proficiency at a B2 level, and 14 participants $(27.5 \%)$ confirmed level B1. Twenty students (39.3\%) displayed A2 level, which is the lowest FCE result that we received during the study. The acceptable levels of English proficiency for the first-year students of language institutes are levels $\mathrm{C} 1, \mathrm{~B} 2$, and B1, which 31 participants (60.7\%) possess, while 20 test subjects (39.3\%) have insufficient competence (Atlasova et al., 2019).For such students as well as for everyone else we offer the following conclusions and recommendations.

\section{Speaking (productive skill}

First-year students of the Institute of Modern Languages and International Studies successfully completed $58.24 \%$ of the tasks of this section. The largest number of mistakes, according to the rating scale, was made in the Use of English section which involves knowledge of grammar and vocabulary. Recommendations are the following:

- Teachers need to choose and mix techniques from different methods, based on a specific situation.

- Practise exercises on common lexical or grammatical mistakes.

- Teaching grammar and vocabulary should be done using communicative approach.

- Communicative tasks should reflect various real life situations because they contribute to the involuntary memorization of speech patterns and their correct use in speech.

- A particularly important factor is the selection and organization of the material based on situations and communication problems that interest students.

- To prepare students for the test, teachers are encouraged to use the teaching aids of foreign publishers, the Cambridge University Press in particular, as an additional component to the curriculum.

\section{Listening (receptive skill)}

Only $45 \%$ of participants successfully passed this test, which confirms the insufficient level of preparation. Suggested recommendations:

- The more students do listening exercises, the faster the level of understanding of audio texts increases.

- During lessons, it is worth paying attention to vocabulary and phrases. Moreover, this aspect also includes different voices, accents, and speech styles.

- Discussion in pairs or groups should be encouraged.

- During listening exercises it is necessary pay attention to pronunciation features of the speakers, e.g. stressed syllables and words in sentences (bearing semantic load).

- Before starting an audio recording, students should carefully read the assignment or a summary of the text, if given, which helps to develop predicting skills. Students can analyze the possible options for what they hear-for example, if the assignment includes news, they can point out possible places and names; carefully read tasks, questions, and answer options to predict the information in the recording and increase the chances of successful completion of the task. Even if a student did not hear the correct answer, it is 
necessary to fill in the gap. It is important to learn to fully listen to the sentence, without being distracted by individual words (in Task 1, 3, and 4) (Atlasova et al., 2019).

\section{Writing (productive skill).}

The average result in writing was $58.2 \%$. Evaluation criteria: language (variety of words and grammar), communicative achievement (relevance of information, conventions of the format and the register), and content and organization (logic and text cohesion). Typical mistakes: 1. Grammatical accuracy and lexical errors; 2 . Not fully extended or inaccurate answers; 3. Misunderstanding of the task, which impairs text logic and content; 4. Repetition or the use of simple words; 5 . Lack of variety in vocabulary and grammatical structures; 6. Incorrect or inconsistent register; 7. Lack of cohesive devices; 8 . Content insufficiency: some of the students did not add one more content aspect using their own idea in the essay, which is required by the task. Of course, writing is one of the difficult forms of speech activity and includes a large number of operations; therefore, based on the results of the work done, we developed the following recommendations for the written part of the exam:

- Familiarise students with various the format of text types: essay, email or letter, review, article, report. The FCE-oriented tutorials from Cambridge University Press contain all kinds of the assignments and useful tips for successful writing.

- Teachers need to show students how to plan their work for both parts of this paper, this will help to write the text in using logical division into paragraphs, to think about the ideas given in the input and one's own ideas. It is necessary to include all the problems and questions from the assignment because it is possible to get a lower score for writing without errors, but with incomplete information, than for writing with errors but highlighting all the points.

- It is necessary to teach students so that they begin to use a rich vocabulary. This can be achieved by giving students more interesting texts to read, while also working with special study guides and textbooks.

- Train students to focus and develop the ability to self-correct, which is necessary to produce accurate grammar and use various structures, e.g. to demonstrate the knowledge of different tenses.

- And last but not least, it is important to teach students to adhere to the assignment and write within the given word limit.

\section{Reading (receptive skill)}

The average result in Reading (parts 5-7) was 51.23\%. Most mistakes in the group average were made in Part 7 - Multiple Matching - 27 times (most often mistakes were made in Task 43, 45, 46, 49, 50, and 51). In this part students had to match four short texts with questions. Seventeen mistakes were made in Part 6 - Gapped Text (most often in Task 38, 40, and 41). In this part students had to insert missing sentences into the text. The fewest number of mistakes was made in Part 5 - Multiple Choice (most mistakes were made in Task 33, 34, and 36). In this part students had to answer multiple-choice questions. Suggested recommendations:

- Part 5. It is necessary to give students more texts to read and understand their meaning since in this part three answers out of four are incorrect. Moreover, in these incorrect sentences there may be distractors.

- Part 6. Students should do more exercises with gapped texts. To choose the correct answer, it is necessary to carefully read the sentences before and after the gap. Students should practice more at recognizing a wide range of cohesive devices that express the 
logical flow and cohesion of the text, for example, words and phrases indicating periods of time, cause and effect, opposing ideas and contrasts.

- Part 7. Students should practice skimming texts in order to quickly find specific information. In class this can be done in as a game in the form of a competition between several groups. It is also necessary to assign tasks for students to read texts containing opinions, attitudes and feelings (e.g. reviews), etc (Atlasova et al., 2019).

\section{Grammar and vocabulary}

The most difficult paper of the test with the most mistakes in all groups was Use of English (Parts 1-4). The average result was $40.3 \%$. Recommendations for improving this skill are as follows:

- At the first stage it is necessary to explain grammar, which involves the relevant information about the specifics of a particular grammatical phenomenon, and practise the structures in training exercises (controlled practice).

- At the next stage, the task is to provide practice of the grammatical structures in communicative activities using them in various situations where the structures should be repeated.

- Conducting regular formative assessment should provide data on the results of the work done and the appropriateness of the transition to the study of another grammatical structure.

- The stage of controlled practice and the stage of communicative practice, which automate the ability to adequately use the grammatical means of the language, are very important for the effective development of grammatical skills. Then, to achieve absolute awareness and refinement of grammatical material, the use of selective, lacunar, and matrix technological methods is recommended. At the beginning of this stage, it is recommended to do selectively test tasks that provide for the recognition of structures and help systematize the studied theoretical material in a specific block, inducing the development of both receptive and productive grammatical skills.

\section{Acknowledgment}

The authors are grateful to Svetlana Viktorovna Panina, Candidate of Pedagogical Sciences, Associate Professor of the Department of Pedagogy, Pedagogical Institute, NEFU, for her theoretical support and recommendations.

\section{References}

Al-Ameedi, R.T., Ibrahim, E.R., \& Nayef, K.J. (2019). Language Laboratory and Developing Skills in an Iraqi Secondary School. Journal of Southwest Jiaotong University, 54(5). http://jsju.org/index.php/journal/article/view/414

Atlasova, L.A., Jemelianova, V.I., Ivanova, A.V., \& Stepanova, A.S. (2019). Independent Examination of the Level of Communication Skills of First-Year Students of a Linguistics Institute. Ammosov-2019 [E-source]: A Collection of Materials of the University Scientific Conference of NEFU students. Yakutsk, North-Eastern Federal University n.a. Ammosov M.K., April $5^{\text {th }} 2019$, edited by Malyshev N.V. Yakutsk: Publishing house NEFU. 1 CD. Pp. 380-386.

Beretskaya, E.A. (2016). Linguodidactic Aspects of Reading Arts at Various Stages of Learning Russian as a Foreign Language. Philological Sciences. Theoretical and Practical Issues. Tambov: Gramota Publishers.

Cambridge Assessment English [E-source] (2018). Available at: http://www.cambridgeenglish.org.ru/exams-and-tests/qualifications/ (access date: 01.12.2018) 
Cambridge English Qualifications on the CEFR [E-source] (2018). Режим доступа: http://www.cambridgeenglish.org/images/126130-cefr-diagram.pdf [access date: $01.12 .2018]$

Council of Europe. (2001). Council for Cultural Co-operation. Education Committee. Modern Languages Division. Common European Framework of Reference for Languages: learning, teaching, assessment. Cambridge University Press.

Dadiani, T.M. (2011). Learning to Read as the Main Type of Speech Activity. [E-source] Social network of educators "Our Network": [https://www.icivics.org/our-network] URL: http://nsportal.ru (access date: 15.02.2019).

Douglas, B. H., \& Heekyeong, Lee. (2015). Teaching by Principles: An Interactive Approach to Language Pedagogy. Pearson Education ESL; $4^{\text {th }}$ edition. p. 688.

Folomkina, S.K. (1980). Learning to Read in a Foreign Language at a Non-Linguistic University. Moscow.

Galskova, N.D., \& Gez, N.I. (2006). Theory of Teaching Foreign Languages. Linguodidactics and Methods: A Learning Guide for Students of Linguistic Universities and Foreign Language Faculties of Higher Pedagogical Educational Institutions. Moscow: Publishing Center "Academy", 336.

Gez, N.I. (1981). Intensification of Listening Comprehension at the Initial Stage. Foreign Languages, 5, 31 .

Gorokhova, A.I., Popova, E.M., \& Sidorova, M.B. (2017). On the Results of Monitoring the Development of Foreign Language Communicative Competence among Schoolchildren Using International Tools for Assessing Language Knowledge. Electronic Scientific Edition (pedagogical and psychological sciences) The Emissia. Offline letters. 8 [Esource] - Available at: http://emissia.org/offline/2017/2554.htm (access date: 04.12.2018).

Graves, M. F., Juel, C., \& Graves, B. B. (1998). Teaching reading in the 21st century. Order Processing, Allyn and Bacon, PO Box 11071, Des Moines, IA 50336-1071.

Jelukhina, N.V. (1989). Learning to Listen in Line with a Communicative-Oriented Methodology, Foreign Languages in School, 2, 23-26.

Kornienko, E.R. (1996). Semantic Perception and Understanding of the Text during Reading. Moscow.

Mescheryakov, D. (2018). English Proficiency Rating Systems and Exams. English. Otradnoe. [E-source]. Available at: http://emissia.org/offline/2017/2554.htm (access date: 05.12.2018)

Numan, D., \& Lamb, C. (1996). The self-directed teacher. Cambridge: CUP. The Oxford-Duden Pictorial English Dictionary. // Oxford: Oxford University Press, 1995.

Shevchenko, N.I. (2002). Methods of Teaching Introductory Reading at a Non-Linguistic University. Moscow.

The Specification of Control Measuring Materials for the Unified State Exam in Foreign Languages in 2018 [E-source]. Available at: http://www.fipi.ru/ege-i-gve-11/demoversiispecifikacii-kodifikatory [access date: 04.12.2018]

Vtorushina, N.J. (2010). Writing and Written Speech in Foreign Language Learning. Almanac of Modern Science and Education. Tambov: Gramota Publishers, 1 (32), 129-132.

Zimnyaya, I.A. (2001). Linguopsychology of Speech Activity. Moscow. 